\title{
INTERVALOS DE TEMPO ENTRE A DESSECAÇÃO DE PASTAGEM DE AZEVÉM E A SEMEADURA DE FEIJÃO, SOJA E MILHO
}

\section{TIME INTERVALS BETWEEN THE RYEGRASS PASTURE DESICCATION AND THE COMMON BEAN, SOYBEAN AND CORN SOWING}

\author{
Alvadi Antonio BALBINOT JR. ${ }^{1}$ \\ Gilcimar Adriano $\mathrm{VOGT}^{2}$ \\ Michelangelo Muzell TREZZI \\ Milton da VEIGA ${ }^{4}$
}

\begin{abstract}
RESUMO
Na região Sul do Brasil é comum o cultivo de feijão, soja e milho após pastagem anual de inverno, em sistema integração lavoura-pecuária. O objetivo desse trabalho foi avaliar o efeito de intervalos de tempo entre a dessecação de pastagem de azevém e a semeadura de feijão, soja e milho sobre o desempenho das culturas, em plantio direto. Foram conduzidos três experimentos, um para cada cultura, em Major Vieira, SC, na safra 2009/10, em delineamento inteiramente casualizado, com três repetições. Foram avaliados quatro intervalos de tempo entre a dessecação do azevém e a semeadura das culturas: $0,10,22$ e 31 dias. Dessecações de azevém próximas à semeadura das três culturas conferiram maior quantidade de palha e cobertura do solo por esta no momento da semeadura, mas reduziram a cobertura do solo por plantas de feijão, soja e milho no início do ciclo de desenvolvimento. Contudo, a produtividade de grãos e os seus componentes (número de plantas por área, número de vagens/espigas por planta, número de grãos por vagem/espiga e massa do grão) não foram afetados pelos intervalos de tempo entre a dessecação do azevém e a semeadura de feijão, soja e milho. plantio direto.

Palavras-Chave: Lolium multiflorum; Phaseolus vulgaris; Glycine max; Zea mays; integração lavoura-pecuária;
\end{abstract}

\begin{abstract}
In crop-livestock system in Southern Brazil is usual the common bean, soybean and corn cropping after annual winter pasture. The objective of this work was to evaluate the effect of time intervals between ryegrass desiccation and the common bean, soybean and corn sowing on crop performance, in no-tillage system. Three experiments were carried out in Major Vieira, Santa Catarina, Southern Brazil, in 2009/10 crop season. The experimental design was a completely randomized, with three replications. Were evaluated four time intervals between ryegrass desiccation and sowing crops: 0,10 , 22 and 31 days. Ryegrass desiccation near the common bean, soybean and corn sowing showed higher straw production and straw cover at sowing, but decreased the soil cover by crops plants in the beginning of their cycle. However, the grain yields and its components (number of plants per area, number of pods/ears per plant, number of grains per pod/ear and grains mass) were not affected by time intervals between ryegrass desiccation and crops sowing.
\end{abstract}

Key Words: Lolium multiflorum; Phaseolus vulgaris; Glycine max; Zea mays; crop-livestock system; no-tillage.

\footnotetext{
1 Eng. Agr., Dr., pesquisador da Embrapa Soja, Rodovia Carlos João Strass, Distrito de Warta, Londrina, PR, 86001-970, balbinot@cnpso.embrapa.br

$\frac{\text { balbinot@cnpso.embrapa.br }}{2}$ Eng. Agr., MSc., Epagri/Estação Experimental de Canoinhas, SC, Brasil. E-mail: gilcimar@epagri.sc.gov.br

${ }^{3}$ Eng. Agr., Dr., UTFPR/Campus Pato Branco, Pato Branco, PR, Brasil. E-mail: trezzi@utfpr.edu.br

${ }^{4}$ Eng. Agr., Dr., Epagri/Estação Experimental de Campos Novos, Campos Novos, SC, Brasil. E-mail: milveiga@epagri.sc.gov.br
} 
BALBINOT JR., A.A. et al. Intervalo de tempo entre a dessecação...

\section{INTRODUÇÃO}

$\mathrm{Na}$ região Sul do Brasil, é comum o cultivo de feijão, soja e milho em sucessão a pastagens anuais de inverno, em sistema integração lavourapecuária. Este sistema proporciona maior diversidade de atividades econômicas na propriedade rural, podendo conferir vantagens biológicas e econômicas (Balbinot Jr. et al., 2009). Entre as espécies forrageiras anuais de inverno, o azevém é muito cultivado no Sul do Brasil, principalmente porque é adaptado a essa região, fornece forragem de alta qualidade no inverno e início da primavera e possui a capacidade de ressemeadura natural. Essa espécie forma palha com alta porcentagem de cobertura do solo e elevada capacidade de suprimir a emergência e o acúmulo de massa em várias espécies daninhas (Moraes et al., 2009).

O intervalo de tempo entre a dessecação da cobertura vegetal e a semeadura de culturas estivais é prática importante que afeta a disponibilidade de nitrogênio (N) (Silva et al., 2006) e a infestação de plantas daninhas (Balbinot Jr. et al., 2007). Foram realizados estudos sobre intervalos de tempo entre a dessecação de culturas para cobertura do solo no inverno em relação à semeadura de milho (Neves et al., 1999; Constantin et al., 2009) e soja (Constantin et al., 2005). Há certa discrepância entre resultados acerca dos efeitos desses intervalos sobre o desempenho produtivo do milho. Isso decorre, provavelmente, das diferentes condições experimentais, referentes ao ambiente e à genética das plantas utilizadas.

No caso de sistema integração lavourapecuária, não há informações na literatura acerca dos efeitos de diferentes períodos entre a dessecação da pastagem de azevém e a semeadura de culturas estivais sobre o desenvolvimento e produtividade dessas. Se por um lado a dessecação antecipada do azevém pode melhorar a disponibilidade de $\mathrm{N}$ às culturas estivais, por outro reduz a cobertura do solo com palha no início do ciclo dessas, o que pode se refletir em aumento da evaporação e da temperatura do solo, maior infestação de plantas daninhas e redução da ressemeadura natural dessa pastagem.

O objetivo desse trabalho foi avaliar o efeito de intervalos de tempo entre a dessecação de azevém utilizado em pastejo e a semeadura de feijão, soja e milho sobre o desempenho produtivo dessas culturas estivais, em plantio direto.

\section{MATERIAL E MÉTODOS}

Foram conduzidos três experimentos em Major Vieira, SC, na safra 2009/10, em solo classificado como Latossolo Vermelho distrófico (Embrapa, 1999), um com feijão, um com soja e outro com milho. As coordenadas geoprocessadas do local dos ensaios são $26^{\circ} 19^{\prime}$ sul, $50^{\circ} 27^{\prime}$ oeste e altitude de 840 metros. O delineamento experimental utilizado foi o inteiramente casualizado, com três repetições. Foram avaliados quatro intervalos de tempo entre a dessecação de pastagem de azevém e a semeadura de feijão, soja e milho: 0, 10, 22 e 31 dias. Nas três culturas, cada parcela possuía 22,5 $\mathrm{m}^{2}(4,5 \times 5,0 \mathrm{~m})$.

$\mathrm{O}$ azevém foi semeado a lanço, em abril de 2009 , sendo pastejado de junho até a primeira dessecação, efetuada em 20/10/2009. O pastejo foi realizado por bovinos mestiços em terminação, em sistema de pastejo contínuo, com lotação média de 1,5 unidades animais por hectare, a qual proporcionou altura média de plantas de, aproximadamente $10 \mathrm{~cm}$. Na pastagem de azevém não foi realizada nenhuma adubação.

As dessecações do azevém foram realizadas com glyphosate, na dose $960 \mathrm{~g}$ i.a. ha ${ }^{-1}$, mais óleo mineral $\left(1,5 \mathrm{~L} \mathrm{ha}^{-1}\right)$, aplicados com pulverizador costal, em volume de calda de $200 \mathrm{~L} \mathrm{ha}^{-1}$. As dessecações foram realizadas nos seguintes dias: 20/10/2009; 29/10/2009; 10/11/2009; e 20/11/2009. As condições atmosféricas nos momentos das dessecações eram favoráveis à ação do herbicida, com temperatura do ar entre 20 e $26^{\circ} \mathrm{C}$, ausência de orvalho sobre as folhas, alta umidade do solo e ausência de chuva após 10 horas da aplicação. Junto com as dessecações, aplicou-se o inseticida cipermetrina (50 g i.a. ha ${ }^{-1}$ ).

No dia 20/11/2009 foram semeadas as culturas estivais, com auxílio de semeadora para plantio direto equipada com facão sulcador, com profundidade de ação de $12 \mathrm{~cm}$. As cultivares de feijão, soja e milho utilizadas foram IPR-Graúna, Coodetec 206 e SCS155 Catarina, respectivamente. As adubações de base e de cobertura foram as recomendadas a partir da análise do solo (Sociedade..., 2004). $\mathrm{O}$ espaçamento entre fileiras foi de $0,45 \mathrm{~m}$ para as três espécies. Na semeadura foi utilizado o dobro da quantidade de sementes pretendida, a fim de ajustar a densidade de plantas em 200 mil plantas $\mathrm{ha}^{-1}$ para o feijão e soja e 50 mil plantas ha ${ }^{-1}$ para o milho, por meio de raleio manual. As demais práticas de manejo foram aquelas recomendadas para as culturas.

Antes da semeadura das culturas e durante o ciclo dessas foram avaliadas as seguintes variáveis: quantidade de palha de azevém no momento da semeadura das culturas estivais, por meio de coleta da palha presente em $1 \mathrm{~m}^{2}$ em cada parcela, a qual foi seca em temperatura de $65^{\circ}$ e determinada a massa em balança de precisão, sendo após realocada na mesma posição de onde foi retirada; porcentagem de cobertura do solo com palha no dia da semeadura das culturas estivais; porcentagem de solo descoberto aos 15 e 31 dias após a semeadura (DAS) do feijão e da soja, e, no caso do milho, apenas aos 15 DAS; porcentagem de cobertura do solo com plantas de feijão e soja aos 15 e 31 DAS, e, no caso do milho, apenas aos 15 DAS. As porcentagens de cobertura foram estimadas por meio de fotos obtidas a $1,5 \mathrm{~m}$ da superfície do solo, as quais focaram três fileiras de plantas cultivadas. Sobre essas fotos foram posicionados 100 pontos sem preenchimento, na forma de grid. Após, houve contagem de pontos preenchidos com palha, plantas e solo, sendo os dados apresentados em porcentagem; número de plantas emergidas em cinco metros de fileira aos 15 DAS, a fim de verificar o estabelecimento das plantas cultivadas; altura de 
BALBINOT JR., A.A. et al. Intervalo de tempo entre a dessecação...

plantas e diâmetro do caule no momento da colheita, determinados em 10 plantas por parcela, coletadas de forma aleatória; número de vagens/espiga por planta e número de grãos por vagem/espiga em 10 plantas por parcela, coletadas de forma aleatória; massa de mil grãos por parcela; e produtividade de grãos, estimada pela colheita de grãos na área útil de cada parcela $\left(3,6 \mathrm{~m}^{2}\right)$, sendo os dados corrigidos para $13 \%$ de umidade.

Os dados coletados foram submetidos à análise de variância e teste $\mathrm{F}$. Quando houve efeito de tratamentos a $5 \%$ de probabilidade do erro, os dados foram submetidos à análise de regressão polinomial, utilizando-se os modelos que melhor se ajustaram aos dados e ao fenômeno investigado. Também foi determinado o coeficiente de correla- ção linear de Pearson entre a quantidade de palha e a cobertura do solo promovida por esta no momento de semeadura das culturas estivais.

\section{RESULTADOS E DISCUSSÃO}

A quantidade de palha remanescente e a cobertura do solo no momento da semeadura do feijão, soja e milho foram afetadas pelos tratamentos (Figura 1). Quanto maior foi o intervalo de tempo entre a dessecação e a semeadura da cultura, menor a quantidade de palha e a cobertura do solo promovida por esta. Isso ocorreu porque neste período parte da massa vegetal dessecada se decompôs, além disso, as plantas de azevém, depois de dessecadas, não apresentaram crescimento.
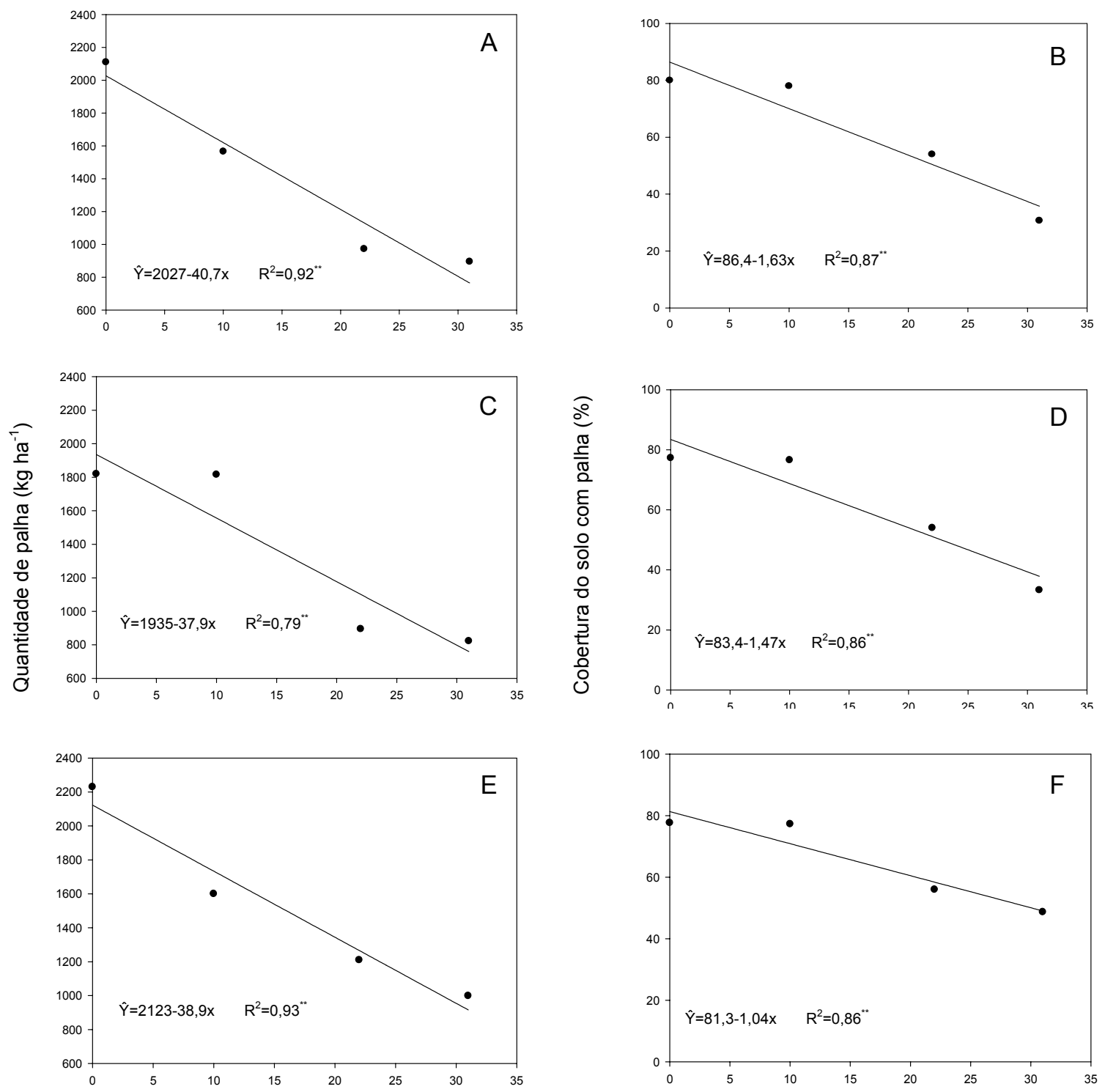

Dias entre a dessecação e a semeadura

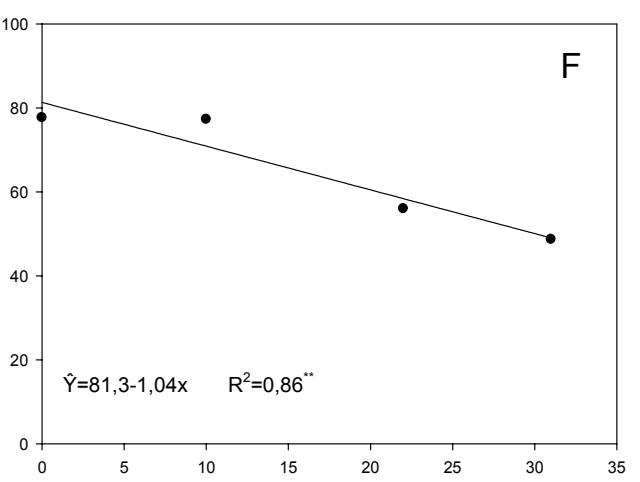

Dias entre a dessecação e a semeadura

FIGURA 1 - Quantidade de palha sobre o solo e cobertura do solo com palha no momento da semeadura do feijão $(A)$ e (B), soja (C) e (D) e milho (E) e (F), em diferentes intervalos de tempo entre a dessecação da pastagem de azevém e a semeadura das culturas. ${ }^{* *}$ Significativo $(P \leq 0,01)$. 
BALBINOT JR., A.A. et al. Intervalo de tempo entre a dessecação...

Verifica-se que houve associação entre a quantidade de palha e a porcentagem de cobertura do solo por esta (Figura 1). Para o experimento de feijão esta correlação foi de 0,61 , no experimento de soja foi de 0,84 e no milho foi de 0,67 . Com maior quantidade de palha sobre o solo, considerando a mesma espécie vegetal, há tendência de haver maior cobertura do solo (Theisen et al., 2000). Quando a dessecação do azevém ocorreu 31 dias antes da semeadura, a quantidade de palha na semeadura das culturas estivais foi de apenas $814 \mathrm{~kg}$ $\mathrm{ha}^{-1}$, na média das três culturas, e a cobertura do solo com palha foi de apenas $41 \%$. Por outro lado, quando a dessecação ocorreu no dia da semeadura do feijão, soja e milho a quantidade de palha no
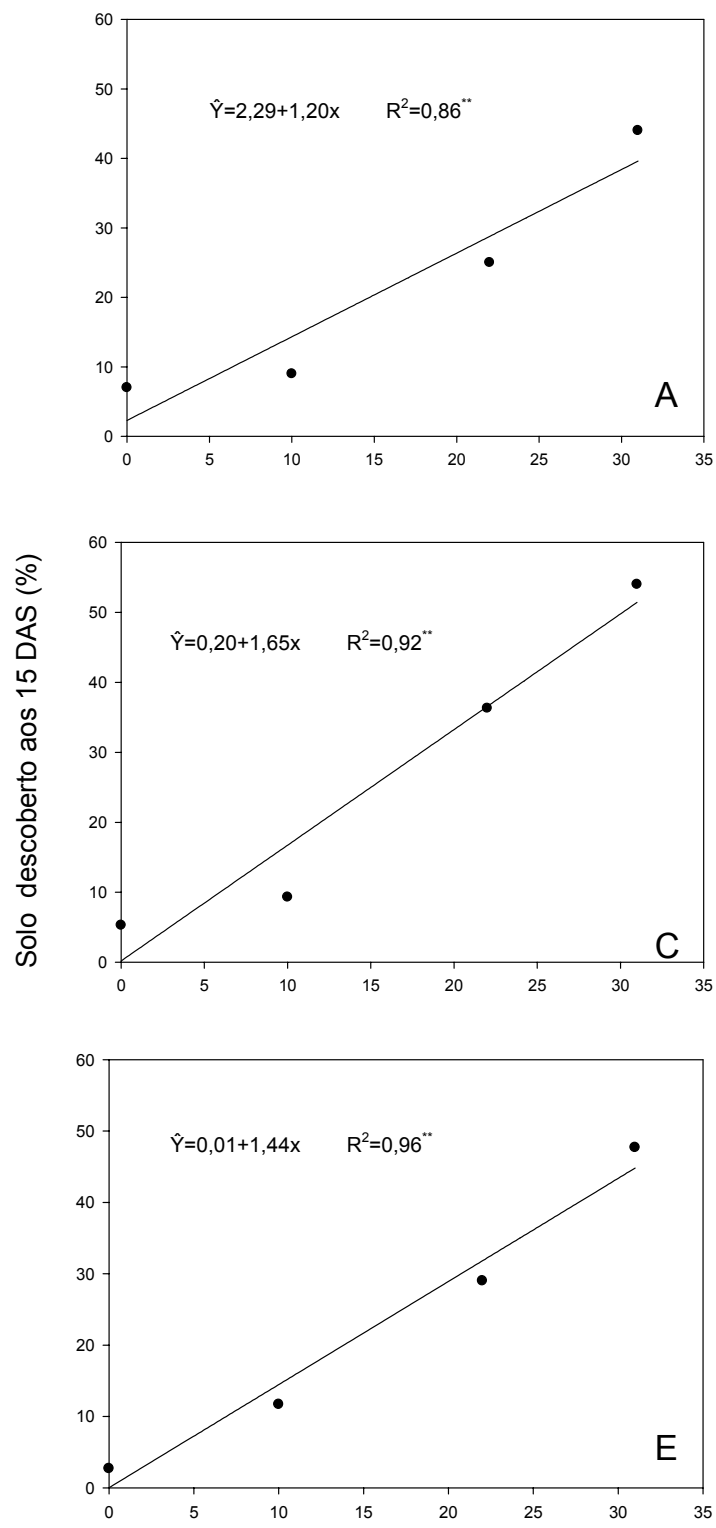

Dias entre a dessecação e a semeadura momento da semeadura foi de 2027, 1953 e 2123 $\mathrm{kg} \mathrm{ha}^{-1}$ e a cobertura do solo com palha foi de 86 , 83 e $81 \%$, respectivamente. O aumento da cobertura do solo com palha pode reduzir a evaporação, a amplitude de temperatura do solo (Veiga, 2005) e a infestação de plantas daninhas (Balbinot et al., 2007), sendo fundamental em sistema plantio direto.

Com o aumento do intervalo de tempo entre a dessecação e a semeadura das culturas estivais houve aumento da porcentagem de solo descoberto avaliada aos 15 e 31 DAS (Figura 2). Isso ocorreu devido a menor quantidade de palha presente sobre o solo quando houve dessecação antecipada (Figura 1).

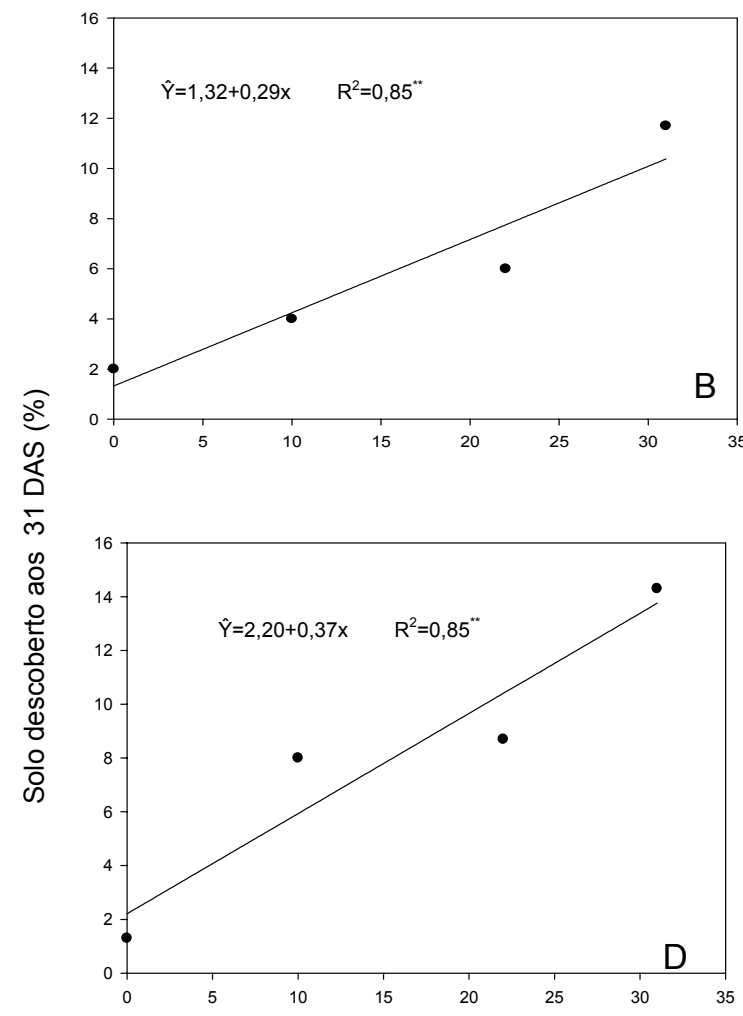

Dias entre a dessecação e a semeadura

FIGURA 2 - Porcentagem de solo descoberto aos 15 e 31 dias após a semeadura (DAS) do feijão (A) e (B) e da soja (C) e (D) e aos 15 DAS do milho (E), em diferentes intervalos de tempo entre a dessecação da pastagem de azevém e a semeadura das culturas. ${ }^{* *}$ Significativo $(P \leq 0,01)$. 
BALBINOT JR., A.A. et al. Intervalo de tempo entre a dessecação...

A dessecação antecipada proporcionou maior velocidade de crescimento inicial das plantas estivais, especialmente de feijão, o que se refletiu na maior porcentagem de solo coberto com o aumento do intervalo de tempo entre a dessecação e a semeadura das culturas (Figura 3). Provavelmente isso ocorreu porque a antecipação da dessecação fez com que o pico de imobilização de nitrogênio pelos microrganismos na decomposição da paIha não coincidisse com o pico de requerimento de nitrogênio pelas culturas. Esse fato foi documentado
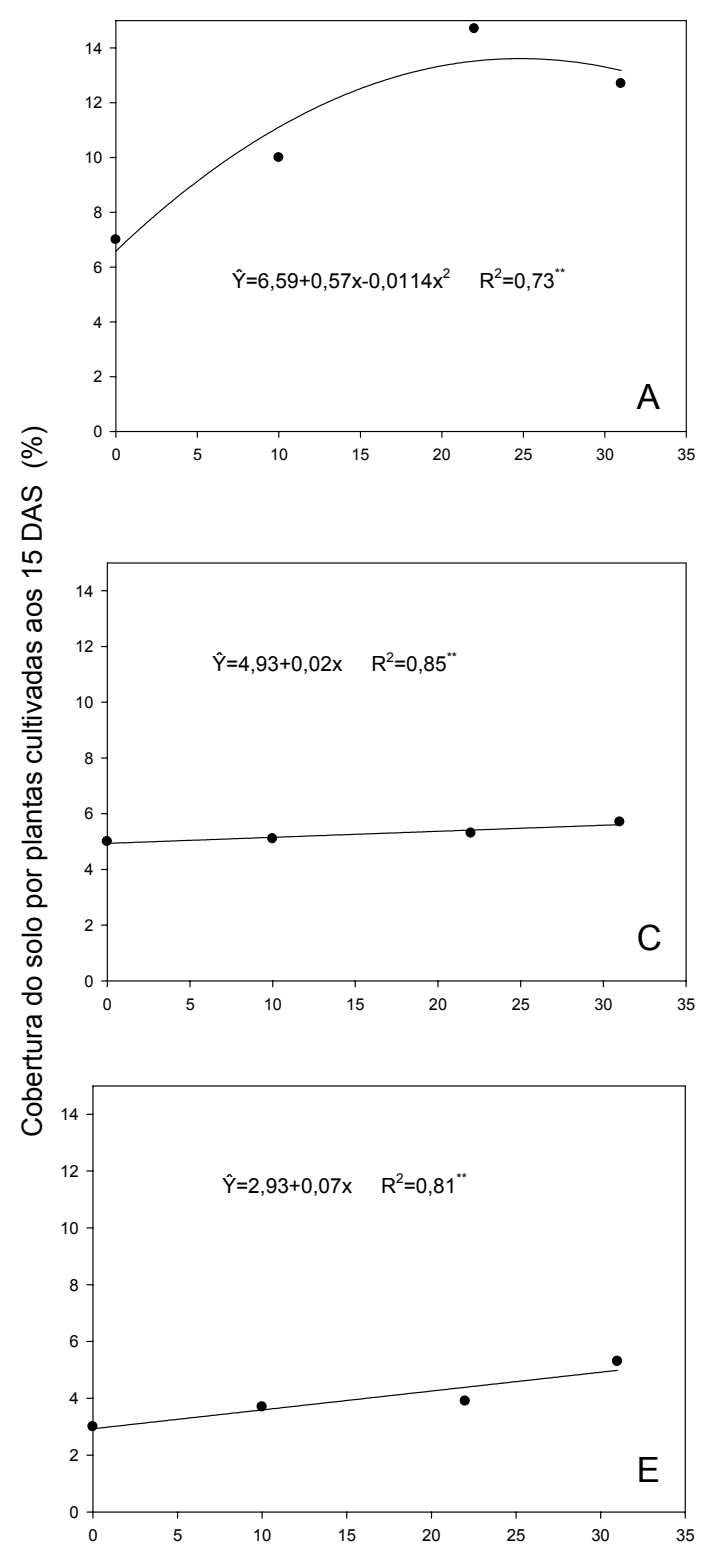

Dias entre a dessecação e a semeadura na cultura de milho semeada após gramíneas invernais, como aveia-preta (Silva et al., 2006). Além disso, é possível que a menor cobertura do solo decorrente da dessecação antecipada possa ter proporcionado maior temperatura do solo no início do ciclo das culturas anuais, aumentando sua velocidade de crescimento. A cobertura do solo com palha reduz o aquecimento do solo no período diurno, principalmente devido à alta reflexão da radiação solar pela palha (Teasdale \& Mohler, 1993; Veiga, 2005).

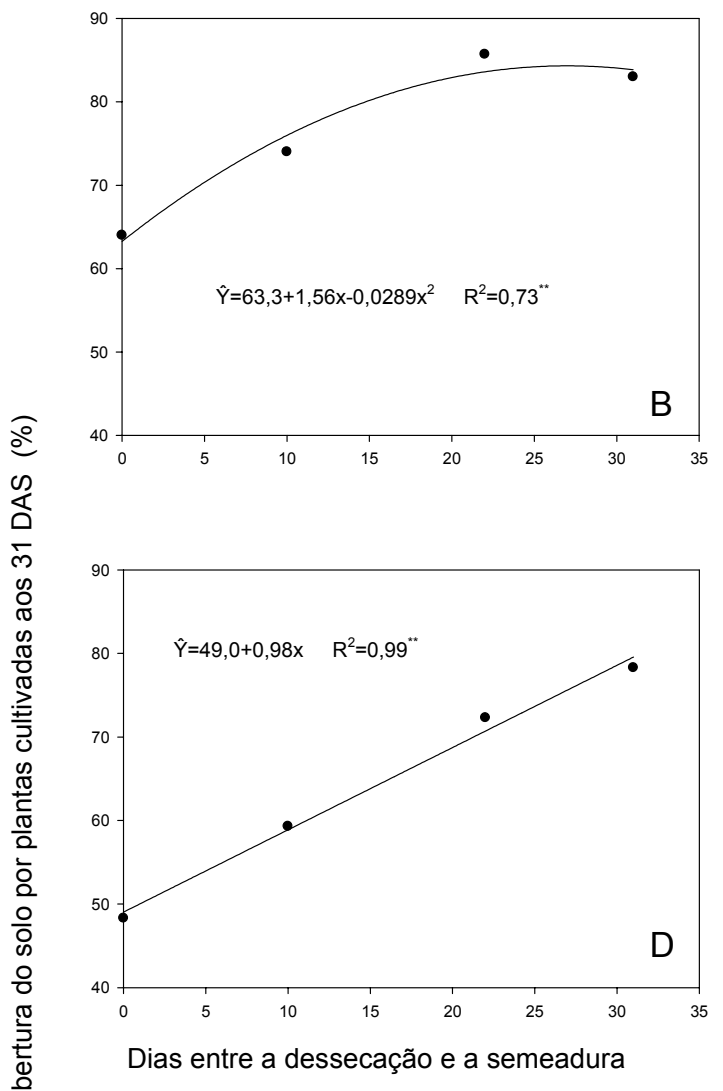

FIGURA 3 - Porcentagem de solo coberto pelas plantas cultivadas aos 15 e 31 dias após a semeadura (DAS) do feijão (A) e (B) e da soja (C) e (D) e aos 15 DAS do milho (E), em diferentes intervalos de tempo entre a dessecação da pastagem de azevém e a semeadura das culturas. ${ }^{*}$ Significativo $(P \leq 0,01)$. 
BALBINOT JR., A.A. et al. Intervalo de tempo entre a dessecação...

Não houve influência dos tratamentos sobre a emergência de plantas, altura final de plantas e diâmetro do caule nas três culturas testadas (Tabela 1). Isso indica que a antecipação da dessecação provocou maior velocidade de cobertura do solo pelas plantas no primeiro mês após a semea- dura (Figura 3), mas, ao final do ciclo, a estatura de plantas e o diâmetro do caule foram similares entre tratamentos. Adicionalmente, em dessecação realizada no dia de semeadura não houve prejuízo à emergência de plantas, permitindo formação de densidade de plantas adequada.

TABELA 1 - Número de plantas emergidas, altura de plantas e diâmetro do caule em diferentes intervalos de tempo entre a dessecação da pastagem de azevém e a semeadura de feijão, soja e milho.

\begin{tabular}{|c|c|c|c|}
\hline $\begin{array}{c}\text { Intervalos entre } \\
\text { dessecação e } \\
\text { semeadura (dias) }\end{array}$ & $\begin{array}{l}\mathrm{N}^{\circ} \text { de plantas em cinco metros } \\
\text { de fileira, antes do raleio }\end{array}$ & $\begin{array}{l}\text { Altura de plantas na } \\
\text { colheita }(\mathrm{cm})\end{array}$ & Diâmetro do caule $(\mathrm{mm})$ \\
\hline & & Feijão & \\
\hline 0 & $85,3^{\mathrm{ns}}$ & $68,7^{\mathrm{ns}}$ & $7,1^{\text {ns }}$ \\
\hline 10 & 82,7 & 70,6 & 7,7 \\
\hline 22 & 97,0 & 68,2 & 7,1 \\
\hline 31 & 84,7 & 73,6 & 6,9 \\
\hline Médias & 87,4 & 70,3 & 7,1 \\
\hline \multirow[t]{2}{*}{ C.V.(\%) } & 13,4 & 13,2 & 8,5 \\
\hline & & Soja & \\
\hline 0 & $48,3^{\text {ns }}$ & $115^{\mathrm{ns}}$ & $7,0^{\text {ns }}$ \\
\hline 10 & 54,0 & 113 & 7,6 \\
\hline 22 & 52,7 & 111 & 7,9 \\
\hline 31 & 53,7 & 114 & 6,9 \\
\hline Médias & 52,2 & 113 & 7,3 \\
\hline \multirow[t]{2}{*}{ C.V.(\%) } & 6,5 & 3,7 & 15,5 \\
\hline & & Milho & \\
\hline 0 & $19,0^{\text {ns }}$ & $317^{\text {ns }}$ & $24,0^{\text {ns }}$ \\
\hline 10 & 20,0 & 323 & 23,8 \\
\hline 22 & 19,3 & 312 & 23,0 \\
\hline 31 & 16,3 & 300 & 22,4 \\
\hline Médias & 18,7 & 312 & 23,3 \\
\hline C.V.(\%) & 7,9 & 6,1 & 5,4 \\
\hline
\end{tabular}

${ }^{\text {ns }}$ Diferenças não significativas a $5 \%$ de probabilidade do erro.

A produtividade de grãos e os componentes de rendimento (número de vagens/espiga por planta, número de grãos por vagem/espiga e massa de mil grãos) também não foram afetados pelos tratamentos (Tabela 2). É importante salientar que em dessecação no mesmo dia da semeadura das culturas estivais, a quantidade de palha de azevém não foi alta, ao redor de $2 \mathrm{t} \mathrm{ha}^{-1}$. Em situação de maior quantidade de palha de azevém poderia ocorrer alguma redução de produtividade, especialmente em milho, em decorrência do baixo intervalo en- tre a dessecação e semeadura, devido a efeitos alelopáticos e imobilização de nitrogênio para decomposição da palha coincidindo com o pico de requerimento deste nutriente pelo milho (Constantin et al., 2009). Além disso, a palha presente nos três experimentos era composta em grande parte por folhas, com relação carbono/nitrogênio menor do que colmos frequentemente observados em azevém sem pastejo, o que reduz a imobilização de $\mathrm{N}$ para a decomposição. 
BALBINOT JR., A.A. et al. Intervalo de tempo entre a dessecação...

TABELA 2 - Produtividade de grãos e componentes do rendimento de feijão, soja e milho cultivado em diferentes intervalos de tempo entre a dessecação da pastagem de azevém e a semeadura das culturas.

\begin{tabular}{|c|c|c|c|c|}
\hline $\begin{array}{l}\text { Intervalos entre } \\
\text { dessecação e } \\
\text { semeadura (dias) }\end{array}$ & $\begin{array}{l}\text { Produtividade de } \\
\text { grãos } \\
\left(\mathrm{kg} \mathrm{ha}^{-1}\right)\end{array}$ & $\begin{array}{c}\mathrm{N}^{\circ} \text { de vagens/ } \\
\text { espigas por planta }\end{array}$ & $\begin{array}{l}\mathrm{N}^{\circ} \text { de grãos por } \\
\text { vagem/espiga }\end{array}$ & $\begin{array}{l}\text { Massa de mil } \\
\text { grãos } \\
\text { (g) }\end{array}$ \\
\hline \multicolumn{5}{|c|}{ Feijão } \\
\hline 0 & $2840^{\mathrm{ns}}$ & $13,3^{\mathrm{ns}}$ & $5,70^{\mathrm{ns}}$ & $242,6^{\mathrm{ns}}$ \\
\hline 10 & 2824 & 15,6 & 5,82 & 238,3 \\
\hline 22 & 2338 & 13,1 & 5,07 & 222,3 \\
\hline 31 & 2361 & 13,0 & 5,74 & 224,0 \\
\hline Médias & 2590 & 13,7 & 5,59 & 231,8 \\
\hline C.V.(\%) & 10,8 & 14,7 & 8,8 & 3,5 \\
\hline \multicolumn{5}{|c|}{ Soja } \\
\hline 0 & $3137^{\text {ns }}$ & $56,7^{\mathrm{ns}}$ & $2,40^{\mathrm{ns}}$ & $160,3^{\text {ns }}$ \\
\hline 10 & 3428 & 53,3 & 2,65 & 172,2 \\
\hline 22 & 3457 & 65,2 & 2,41 & 173,3 \\
\hline 31 & 3276 & 62,3 & 2,41 & 165,9 \\
\hline Médias & 3325 & 59,4 & 2,47 & 167,9 \\
\hline C.V.(\%) & 15,5 & 25,3 & 4,9 & 6,3 \\
\hline \multicolumn{5}{|c|}{ Milho } \\
\hline 0 & $6472^{\text {ns }}$ & $0,86^{\text {ns }}$ & $359^{\text {ns }}$ & $362,7^{\text {ns }}$ \\
\hline 10 & 8899 & 0,84 & 387 & 363,7 \\
\hline 22 & 6601 & 0,88 & 366 & 354,9 \\
\hline 31 & 6284 & 0,86 & 383 & 359,3 \\
\hline Médias & 7064 & 0,86 & 374 & 360,2 \\
\hline C.V.(\%) & 23,9 & 12,1 & 5,8 & 4,7 \\
\hline
\end{tabular}

${ }^{\text {ns }}$ Diferenças não significativas a $5 \%$ de probabilidade do erro.

Nesse sentido, é possível realizar a dessecação do azevém pastejado próximo à semeadura de feijão, soja e milho, a fim de ter o solo com alta cobertura com palha e maior ressemeadura de azevém, melhorando a formação da pastagem após a colheita das culturas estivais em sistema integração lavoura-pecuária.

\section{CONCLUSÃO}

Intervalos de 0 a 31 dias entre a dessecação de pastagem de azevém à semeadura de feijão, soja e milho não interferiram no desempenho produtivo das culturas estivais em plantio direto.

\section{REFERÊNCIAS}

1. BALBINOT JR., A.A. et al. Épocas de dessecação de coberturas de inverno em relação à semeadura de milho: infestação de plantas daninhas e produtividade da cultura. Scientia Agraria, v. 8, n. 2, p. 111-117, 2007.

2. BALBINOT JR., A.A. et al. Integração lavoura-pecuária: intensificação de uso de áreas agrícolas. Ciência Rural, $v$. 39, n. 6, p. 1925-1933, 2009.

3. CONSTANTIN, J. et al. Dessecação em áreas com grande cobertura vegetal: alternativas de manejo. Informações Agronômicas, n. 111, p. 7-9, 2005.

4. CONSTANTIN, J. et al. Sistemas de dessecação antecedendo a semeadura direta de milho e controle de plantas daninhas. Ciência Rural, v. 39, n. 4, p. 971-976, 2009.

5. EMBRAPA. Centro Nacional de Pesquisa de Solos. Sistema Brasileiro de Classificação de Solos. Brasília: EMBRAPA, 1999. $412 \mathrm{p}$ 
BALBINOT JR., A.A. et al. Intervalo de tempo entre a dessecação...

6. MORAES, P.V.D. et al. Manejo de plantas de cobertura no controle de plantas daninhas na cultura do milho. Planta Daninha, v. 27, n. 2, p. 289-296, 2009.

7. NEVES, R.; FLECK, N.G.; VIDAL, R.A. Intervalo de tempo para semeadura de milho pós-dessecação da cobertura de aveia-preta com herbicidas. Ciência Rural, v. 29, n. 4, p. 603-608, 1999.

8. SILVA, P.R.F. et al. Estratégias de manejo de coberturas de solo no inverno para cultivo do milho em sucessão no sistema semeadura direta. Ciência Rural, v. 36, n. 3, p. 1011-1020, 2006.

9. SOCIEDADE BRASILEIRA DE CIÊNCIA DO SOLO. Manual de adubação e calagem para os Estados do Rio Grande do Sul e de Santa Catarina. 10.ed. Porto Alegre, RS: SBCS/Núcleo Regional Sul; Comissão de Química e Fertilidade do Solo - RS/SC, 2004, 394p.

10. TEASDALE, J.R.; MOHLER, C.L. Light transmittance, soil temperature, and soil moisture under residue of hairy vetch and rye. Agronomy Journal, v. 85, n. 3, p. 673-680, 1993.

11. THEISEN, G.; VIDAL, R.A.; FLECK, N.G. Redução da infestação de Brachiaria plantaginea em soja pela cobertura do solo com palha de aveia-preta. Pesquisa Agropecuária Brasileira, v. 35, n. 4, p. 753-756, 2000.

12. VEIGA, M. Propriedades de um Nitossolo Vermelho após nove anos de uso de sistemas de manejo e efeito sobre culturas. 2005. 110 f. Tese (Doutorado em Ciência do Solo - Processos Físicos e Morfogenéticos do Solo) - Universidade Federal de Santa Maria, Santa Maria, 2005.

Recebido em 07/10/2011

Aceito em 29/03/2011 